\title{
Independence and Fraud Detection: Influence on The Professionalism of Forensic Auditor
}

\author{
Tries Ellia Sandari \\ Faculty of Economic and Business, \\ 17 Agustus 1945 Surabaya University, Surabaya, Indonesia \\ Tri Ratnawati \\ Faculty of Economic and Business, \\ 17 Agustus 1945 Surabaya, Surabaya, Indonesia \\ Indrawati Yuhertiana \\ Faculty of Economy and Business, \\ Pembangunan Nasional Veteran University, Surabaya
}

\begin{abstract}
This study aims to analyze the influence of this study aimed to analyze the influence of audit risk, and investigative audit techniques, on independence, fraud detection and forensic auditor professionalism in Indonesia. This study uses a survey method conducted for all forensic auditors in Indonesia with $\mathbf{2 0 0}$ forensic auditors who have handled fraud cases. The number of samples used was 116 respondents. Data analysis and hypothesis in this study use Structural Equation Modeling (SEM) with PLS 20.0 software. The results of this study indicate that twelve hypotheses were accepted. The significance of this hypothesis shows directly through audit risk, investigative audit techniques on independence, fraud detection and forensic auditor professionalism, so that the forensic auditor's professionalism in detecting fraud will increase.
\end{abstract}

Keywords: Audit risk, investigative auditing techniques, independence, fraud, detection of fraud, forensic auditors, professionalism

\section{INTRODUCTION}

Based on data from the Indonesia Corruption Watch (ICW) investigation division, there were 482 cases in 2016 and an increase of 576 corruption cases in 2017. The amount of state losses also increased by a figure of Rp 6.5 trillion and a bribe of Rp 211 billion. Meanwhile, according to the Corruption Control Commission (KPK) in Indonesia, in 2016 Transparency International Indonesia announced the achievement of the 2016 Corruption Perception Index - CPI in Indonesia up one rank (from 36 to 37), in 2017 the KPK succeeded in returning state losses of Rp. 276.6 billion. This is the result obtained from corruption cases. "More than Rp 188 billion has been put into the state treasury in the form of PNBP from handling cases.

There are still a small number of professional forensic auditors who have fraud certificates in Indonesia due to a lack of training for forensic auditors in Indonesia. While fraud cases involving many cases of corruption require fraud auditors who have special expertise in this field, according to the Forensic Auditor's Professional Certification Institute (LSP_AF) it is said that along with the increasing number and variety of financial transactions and activities related to financial / non-financial state, Auditors who have forensic expertise in the prevention and handling of fraud / corruption. 
The biggest cause of corruption cases in some private companies and Government departments is collusion that occurs in private companies and individuals, researchers believe that there are less cases found by forensic auditors, intentional or unintentional in some cases of fraud by forensic auditors in an effort implement fraud detection in the private sector and government departments.

So that it requires professionalism for the forensic auditor in solving every case of fraud. Tuannakotta, (2012: 349) explains that a large number of auditors who are experienced in auditing the company's financial statements are hesitant in auditing fraud and investigative audits. Medium according to Piter Simanjuntak (2008). That audit time and risk budget pressures will always affect audit behavior which is a decrease in audit quality.

\section{The Audit Risk}

\section{LITERATURE REVIEW}

Audit risk is the vulnerability of account balances or transactions to material misstatement, audit risk positively influences the auditor's responsibility in detecting fraud (Jaffar et al., 2008) this research was supported by Krambia-Kapardis, (2002) and Matsumura and Tucker, (1997) which concluded that audit risk positively affects the auditor's responsibility in detecting fraud in financial statements.

\section{Investigative Auditing Techniques}

The purpose of an investigative audit is to identify investigations and uncover fraud or crime, approaches, procedures and techniques used in investigative audits that are relatively different from the approaches, procedures and techniques used in financial audits, performance audits or other audits. special purpose (Wahono, 2011). According to (Tuanakotta: 2010) the definition of investigation is an attempt to prove that an investigative audit is a fraud investigation and examination that is used interchangeably.

\section{Independence}

Auditor independence is independence which is the attitude expected from the auditor to not have personal problems in carrying out his duties, which is contrary to the principles of integrity and objectivity and to achieve great quality of performance, an independent attitude is required from the auditor (Andenna Pentaza Swastyami, 2016). If the auditor loses its independence, the audit report produced is not consistent with the fact that it cannot be used as a basis for decision making. A study conducted by Wahyuningtyas (2007) states that independence has a positive effect on the auditor's responsibility in detecting errors and irregularities in financial statements. The results of his study are also supported by research conducted by Widiyastutiand and Pamudji (2009), which states that independence has a positive effect on the auditor's responsibility in detecting fraudulent financial statements, independence must also be owned and maintained by the auditor, this attitude demands the auditor to be fair in every task, he is not justified to benefit anyone. Independence consists of two components, namely: 1 . Independence of mental attitude independence of an attitude is also demanded by the auditor so that he is free from interests and pressure from any party, so fraud can be detected properly, and after fraud has been detected, the auditor does not participate in securing the practice fraud.

\section{Fraud detection}

Fraud detection is very important for auditors because fraud is important to detect. This is the motivation of this research, especially in detecting fraud, auditors must be supported by attitudes of competence, independence, and professionalism (Wahyuningtyas, 2007). Suraida 
(2012) states that experienced auditors will show a higher level of selective attention to relevant information. Arens, et al. (2008) states that auditors must have technical qualifications and experience in the industry they audit, because this will make auditors more likely to find fraud from the clients they audit.

Factors Drivers of Fraud Occurrence by William C Boyton in (Arens 2008: 432) Three fraudulent conditions arising from reported fraudulent financial and misuse of assets are outlined in SAS 99 (AU 316). Triangle Fraud, there are three things that encourage the occurrence of a fraud, namely pressure, opportunity, and rationalization, as follows: the pressure

\section{Professionalism of Forensic Auditor}

According to Theodorrus Tuanakotta (2012), the professionalism of forensic auditors can be defined as the expertise of forensic auditors in conducting audits in accordance with certain expertise and forensic auditor professionalism is very important.

According to Sastiana and Sumarlin, (2016) Professionalism is an element of motivation that contributes to someone to have high performance tasks.

Professional people have greater responsibility because it is assumed that a professional has the ingenuity, knowledge, and experience to understand the impact of the activities carried out (Widyastuti and Pamudji, 2009). According to Arens (2009) professionalism as the responsibility of individuals to behave better than merely obeying the existing laws and regulations of society. A professional is a person who (1) believes that his work is important (dedication to the profession), (2) Provides services for the public (Social Obligations), (3) Requires autonomy as a condition for their services (demands for autonomy), (4) Supports separate rules that differ from other professional rules (Trust in Self-Regulations) and (5) Affiliation with other members of their profession (professional community affiliates).

\section{Hypothesis}

1. Audit risk has a significant effect on the independence.

2. Audit risk has a significantly effect on the detection of fraud.

3. Audit risk has a significant effect on the professionalism of forensic auditors.

4. Investigative audit techniques has a significantly effect on the independence.

5. Investigative audit techniques has a significantly effect on the detection of fraud.

6. Investigative audit techniques has a significantly effect on the professionalism of forensic auditors.

7. Independence has a significantly effect on the detection of fraud.

8. Independence has a significantly effect on the professionalism of forensic auditors.

9. Fraud detection has a significantly effect on the professionalism of forensic Auditors 


\section{Conceptual Framework}

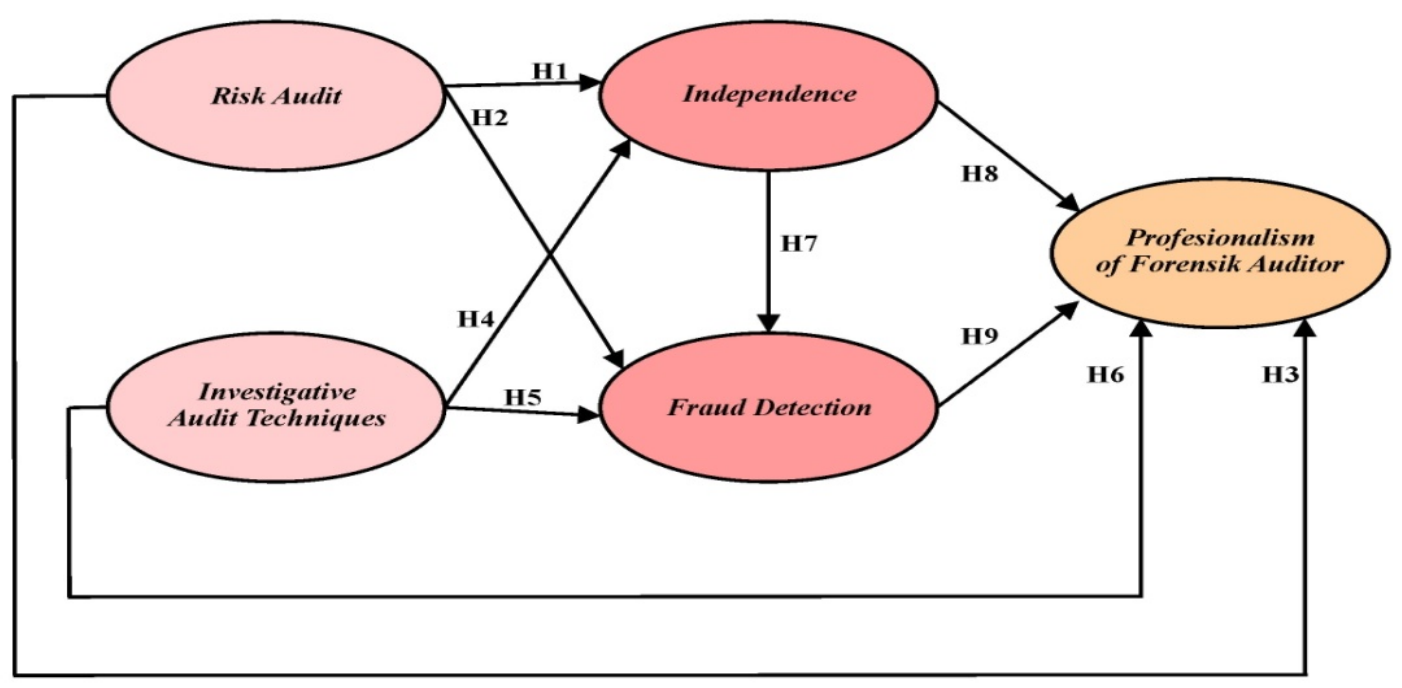

Figure 1. Conceptual Framework of Research

\section{METHODOLOGY}

The object of this research is all forensic auditors. The number of samples of 116 auditors selected by purposive sampling. The sample selection method used is forensic auditors in Indonesia who have handled several fraud cases and are experienced in examining fraud cases for more than two years. To test the proposed hypothesis, the analysis technique used is SEM (Structural Equation Modeling), with PLS statistical software (Ghozali Imam, 2014). While the conceptual framework of research can be seen in Figure 1

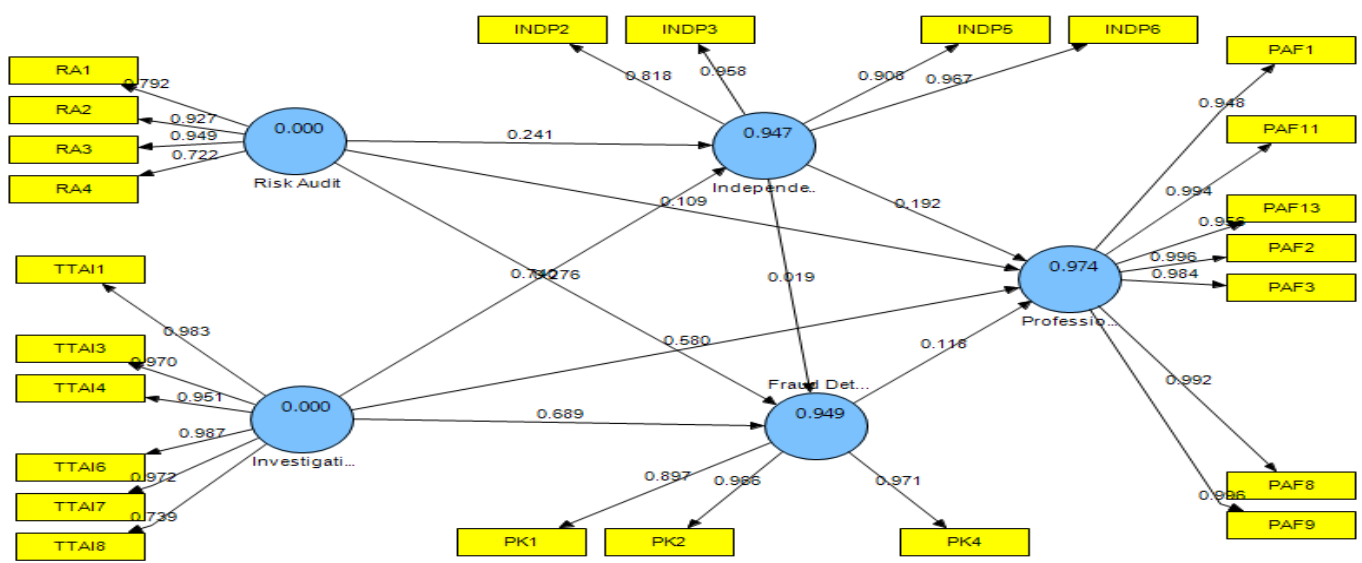

Figure 2. The Output Of Bootstrapping 
Table 2. The Path Coefficient Table 2. The Path Coefficients(Mean, STDEV, T-Values)

\begin{tabular}{|l|c|c|c|c|c|}
\hline & $\begin{array}{c}\text { Original } \\
\text { Sample } \\
\text { (0) }\end{array}$ & $\begin{array}{c}\text { Sample } \\
\text { Mean } \\
\text { (M) }\end{array}$ & $\begin{array}{c}\text { Standard } \\
\text { Deviation } \\
\text { (STDEV) }\end{array}$ & $\begin{array}{c}\text { Standard } \\
\text { Error } \\
\text { (STERR) }\end{array}$ & $\begin{array}{c}\text { T Statistics } \\
\text { (|O/STERR|) }\end{array}$ \\
\hline $\begin{array}{l}\text { (X1) Risk Audit -> (Y) } \\
\text { Professionalism of } \\
\text { Forensic Auditor }\end{array}$ & 0.108859 & 0.109963 & 0.012768 & 0.012768 & 8.525881 \\
\hline $\begin{array}{l}\text { (X1) Risk Audit -> (Z1) } \\
\text { Independence }\end{array}$ & 0.241498 & 0.242595 & 0.011872 & 0.011872 & 20.341037 \\
\hline $\begin{array}{l}\text { (X1) Risk Audit -> (Z2) } \\
\text { Fraud Detection }\end{array}$ & 0.275875 & 0.273732 & 0.016128 & 0.016128 & 17.105044 \\
\hline $\begin{array}{l}\text { (X2) Investigative } \\
\text { Audit Techniques -> } \\
\text { (Y) Professionalism of } \\
\text { Forensic Auditor }\end{array}$ & 0.579660 & 0.579333 & 0.012493 & 0.012493 & 46.397844 \\
\hline $\begin{array}{l}\text { (X2) Investigative } \\
\text { Audit Techniques }-> \\
\text { (Z1) Independence }\end{array}$ & 0.739714 & 0.738743 & 0.011676 & 0.011676 & 63.354857 \\
\hline $\begin{array}{l}\text { (X2) Investigative } \\
\text { Audit techniques -> } \\
\text { (Z2) Fraud Detection }\end{array}$ & 0.688807 & 0.689833 & 0.017452 & 0.017452 & 39.468635 \\
\hline $\begin{array}{l}\text { (Z1) Independence -> } \\
\text { (Y) Professionalism of } \\
\text { Forensic Auditor }\end{array}$ & 0.191970 & 0.191650 & 0.013611 & 0.013611 & 14.103774 \\
\hline $\begin{array}{l}\text { (Z1) Independence }-> \\
\text { (Z2) Fraud Detection }\end{array}$ & 0.018832 & 0.019983 & 0.014771 & 0.014771 & 1.274901 \\
\hline $\begin{array}{l}\text { (Z2) Fraud Detection - } \\
\text { > (Y) Professionalism } \\
\text { of Forensic Auditor }\end{array}$ & 0.117506 & 0.117101 & 0.012164 & 0.012164 & 9.660330 \\
\hline
\end{tabular}

Source: data processed

\section{Hypothesis Testing}

Table 1 shows that all time budget pressure variables, audit risk, investigative audit techniques have a significant effect on the independence, fraud detection and professionalism of forensic auditors in Indonesia with a significance above $5 \%$ with a t-statistic value greater than the ttable value of 1.96 . The original value of the positive estimate shows that all variables have a positive effect, except the independences variable to the fraud detection variable which has a negative effect, this is because high independences will make the auditor unable to detect the gap well. Based on the results of testing using 2.0 PLS gives an answer that the twelve hypotheses were accepted.

\section{SUMMARY}

The results of this study can be concluded: (1) audit risk affect and significant to independence; (2) audit risk affect and significant to fraud detection; (3) Audit risk affect and significantly to professionalism of forensic auditors ; (4) Investigative audit techniques affect and significant to independence;(5) Investigative audit techniques affect and significant to detecting fraud; (6) Investigative audit techniques affect and significant the professionalism of forensic auditors; (7) Independence affect and significantly influence fraud detection; (8) Independence affect and significant the professionalism of forensic auditors; (9) Detection of fraud detection affect and significant to professionalism of forensic auditors. 


\section{BIBLIOGRAPHY}

A.A Putu Ratih Cahaya Ningsih dan P. Dyan Yaniartha, (2013),"Pengaruh Kompensasi, Independensi, dan time Budget Pressure terhadap Kualiatas Audit" E-Jurnal Akuntansi Universitas Udayana 4.1: 92- 109

Andenna Pentaza Swastyami. (2016). “Karakteristik Auditor. Audit Risiko. dan tanggung jawab dalam mendeteks kecurangan”Journal Of Business Accounting. Vol. XV No. 29. 2016.

Arens, et.al. 2008. Auditing and Assurance Services, New Jersey: Pearson Prentice Hall.

https://nasional.tempo.co/read/1062534/kasus-korupsi-tahun-2017-icw-kerugian-negara-rp

https://news.detik.com/berita/d-3787260/kpk-kembalikan-rp-2766-miliar-uang-negara-di-2017

https://www.kpk.go.id/id/publikasi/papers-antikorupsi/488-tantangan-governansi-dalam-menyelesaikanmasalah-korupsi-di-sektor-publik-sektor-swasta

Jaffar et.al.2008. The Effects of the External Auditors' Ability to Assess Fraud Risk on TheirAbility to Detect the Likelihood of Fraud. International Journal of Management Perspectives. ISSN: 1307-1629. 2008.1 (1). 49-70.

Jan Svanberg. Peter Ohman. (2013). Time pressure Auditor: Does the quality of the audit support ethical culture. Managerial Auditing Journal. Journal of emerald Vol. 28 Iss: 7. pp.572 - 591

Krambia-Kapardis. M. 2002. A fraud detection model: a must for auditors, the Journal of Financial Regulation and Compliance, 10 (3). 266-278.

Matsumura and Tucker. 1997. Fraud detection: A theoretical foundation. Fraud detection: A theoretical foundation, The AccountingReview, 67 (4), 753-782.

Suraida, Ida. (2012). “Pengaruh etika, kompetensi, Pengalaman, Risiko Audit dan Skeptisme Profesionalisme Auditor Terhadap Ketepatan Pemberian Opini Akuntan Publik” Vol. 7 No. 3.186 -202.

Tuanakotta, Theodorus M,(2012). Forensic Accounting and Investigative Audit. Jakarta's Salemba Empat.

Widiyastuti, Marcellina and Sugeng Pamudji,(2009). "Pengaruh Kemandirian, kompetensi, dan profesionalisme Menuju kemampuan Auditor dalam mendeteksi Kecurangan, Nilai tambah”. Vol. 5, no. 2

Wahono, Sugeng.2011. Audit Investigation. Narotama University. Surabaya 